\title{
Predicting spatial distribution of postfire debris flows and potential consequences for native trout in headwater streams
}

\author{
Edwin R. Sedell ${ }^{1,3}$, Robert E. Gresswell ${ }^{2,4}$, and Thomas E. McMahon ${ }^{1,5}$ \\ ${ }^{1}$ Fish and Wildlife Ecology and Management Program, Department of Ecology, Montana State University, Bozeman, \\ Montana 59717 USA \\ ${ }^{2}$ US Geological Survey, Northern Rocky Mountain Science Center, Bozeman, Montana 59715 USA
}

\begin{abstract}
Habitat fragmentation and degradation and invasion of nonnative species have restricted the distribution of native trout. Many trout populations are limited to headwater streams where negative effects of predicted climate change, including reduced stream flow and increased risk of catastrophic fires, may further jeopardize their persistence. Headwater streams in steep terrain are especially susceptible to disturbance associated with postfire debris flows, which have led to local extirpation of trout populations in some systems. We conducted a reach-scale spatial analysis of debris-flow risk among 11 high-elevation watersheds of the Colorado Rocky Mountains occupied by isolated populations of Colorado River Cutthroat Trout (Oncorhynchus clarkii pleuriticus). Stream reaches at high risk of disturbance by postfire debris flow were identified with the aid of a qualitative model based on 4 primary initiating and transport factors (hillslope gradient, flow accumulation pathways, channel gradient, and valley confinement). This model was coupled with a spatially continuous survey of trout distributions in these stream networks to assess the predicted extent of trout population disturbances related to debris flows. In the study systems, debris-flow potential was highest in the lower and middle reaches of most watersheds. Colorado River Cutthroat Trout occurred in areas of high postfire debris-flow risk, but they were never restricted to those areas. Postfire debris flows could extirpate trout from local reaches in these watersheds, but trout populations occupy refugia that should allow recolonization of interconnected, downstream reaches. Specific results of our study may not be universally applicable, but our risk assessment approach can be applied to assess postfire debris-flow risk for stream reaches in other watersheds.

Key words: fire, debris flows, channel networks, native trout, Cutthroat Trout, stream habitat, upper Colorado River Basin
\end{abstract}

Cutthroat Trout (Oncorhynchus clarkii) have experienced declines in distribution and abundance throughout the western USA because of habitat fragmentation and degradation and interactions with nonnative species (Gresswell 1988, Behnke 1992, Young 1995). Extant Cutthroat Trout populations generally are confined to mid- to high-elevation streams (>2500 m) with high gradients (Gresswell 1988) and often are isolated by natural or anthropogenic barriers to upstream movement (Kruse et al. 2001, Shepard et al. 2005). Large-scale patterns of habitat occupancy by Cutthroat Trout apparently result from the incursion of nonnative fish species and ubiquitous water development in downstream portions of occupied watersheds (Young 2008). Streams occu- pied by Cutthroat Trout are situated primarily on public lands, particularly those administered by the US Department of Agriculture (USDA) Forest Service (Rieman et al. 2003, Hirsch et al. 2013).

A wide variety of land management activities, including overgrazing, heavy metal pollution, and depletion and diversion of water resources in the upper Colorado River basin, have affected streams occupied by Colorado River Cutthroat Trout (O. c. pleuriticus) (CRCT Coordination Team 2006). Some anthropogenic changes associated with land use (e.g., road culverts and irrigation diversions) have unintentionally isolated upstream populations of Colorado River Cutthroat Trout, thereby protecting them from inva-

E-mail addresses: ${ }^{3}$ Present address: Oregon Department of Fish and Wildlife, La Grande Fish Research, La Grande, Oregon 97850 USA, edwin.r .sedell@state.or.us; ${ }^{4}$ bgresswell@usgs.gov; ${ }^{5}$ tmcmahon@montana.edu

DOI: 10.1086/684094. Received 30 September 2014; Accepted 31 August 2015; Published online 23 September 2015.

Freshwater Science. 2015. 34(4):1558-1570. ๑ 2015 by The Society for Freshwater Science. 
sion by nonnative salmonids and disease (Harig and Fausch 2002). However, fragmented streams restrict trout movement among formerly connected populations, thereby leaving small, isolated populations vulnerable to extirpation by local disturbances (Kruse et al. 2001).

Spatially isolated populations are especially vulnerable to stochastic environmental events (Hilderbrand and Kershner 2000, Peterson et al. 2008, Fausch et al. 2009). Fire may exacerbate extirpation risk for trout populations, either directly (e.g., related to increased temperatures) or indirectly (e.g., because of postfire debris flows; Gresswell 1999). For example, postfire floods and debris flows can scour stream channels to bedrock over long distances, potentially extirpating or severely reducing populations of headwater stream fishes (Propst and Stefferud 1997, Brown et al. 2001, Roghair et al. 2002). Debris flows are important disturbance events that create and maintain a mosaic of stream habitats (Reeves et al. 1995). Debris flows engender sediment and wood inputs to stream channels that can temporarily bury habitat, substrates, and food resources, but these pulse disturbances are generally outweighed by the structural changes (e.g., creation of cover and spawning gravels) that are critical for persistence of stream fishes (Sedell et al. 1990, Benda and Dunne 1997, May and Gresswell 2004).

Postfire floods and debris flows are especially common in the southwestern USA where fires often occur before the onset of the monsoon season (Rinne 1996). Cannon et al. (2010) observed that debris flows in portions of the Rocky Mountains occurred after $\sim 1$ in every 3 fires, with incidence depending on postfire storm events when rainfall intensity exceeded soil infiltration capacity. Most debris flows occur in small $\left(<2.6 \mathrm{~km}^{2}\right)$, steep $(>20 \%)$ basins (Parrett et al. 2003) and usually do not threaten trout populations in entire stream networks (Rieman and Clayton 1997, Gresswell 1999). Most models predicting debris-flow risk were developed for the Pacific Northwest, where rainsaturated soils and steep hillsides are associated with hillslope failures and debris flows (Benda and Cundy 1990, Wondzell and King 2003). In recent years, spatially explicit debris-flow-susceptibility models have been used to identify hazardous areas potentially affecting human infrastructure and lives, particularly after fires (Benda et al. 2007, Cannon et al. 2009, Gartner et al. 2011). For example, Cannon et al. (2010) developed empirical models based on fire extent and severity, basin morphology, and soil and storm rainfall characteristics to estimate the probability of postfire debris flows in recently burned watersheds throughout the intermountain western USA. Each individual model is specific to a particular geographic region, and fire and climatic patterns are used to estimate debris-flow susceptibility in the first few years following a fire (Gartner et al. 2008, Cannon et al. 2009, 2010).

Despite the increased interest in predicting postfire debris-flow risk, few investigators have examined relationships between possible postfire debris flows and populations of aquatic organisms or have attempted to identify potential areas of refuge and risk of local extirpation (Rosenberger et al. 2011, Sestrich et al. 2011, May and Lisle 2012). Current empirical models can identify debris-flow susceptibility at the watershed scale (e.g., Cannon et al. 2010), but they do not provide assessments of debris-flow risk at finer reach scales. Debris-flow effects will be greatest in reaches that receive debris flows directly and through which debris flows travel, as well as on the fan below the drainage basin outlet where most eroded material is deposited. Therefore, evaluating risk to native trout populations requires information related to the specific locations of debris flow inputs and paths and the distribution of trout in the stream network. However, such assessments can be difficult because they require extensive information on the topographies, gradients, geomorphologies, and other fine-scale characteristics of individual tributary drainages, reaches, and junctions.

We conducted a fine-scale spatial analysis of debrisflow risk among 11 high-elevation watersheds in the Colorado Rocky Mountains occupied by remnant populations of Colorado River Cutthroat Trout. We developed a reach-scale debris-flow risk-assessment model based on use of digital elevation models (DEMs) to develop a set of geomorphological characteristics that influence the initiation, propagation, and deposition of debris flows. This model was coupled with a spatially continuous survey of trout distributions across stream reaches to estimate the potential extent of population disturbances associated with possible postfire debris flows. Specific objectives were to: 1) identify watersheds of the upper Colorado River basin that currently support isolated populations of Colorado River Cutthroat Trout; 2) identify geomorphologically distinct stream reaches that support Colorado River Cutthroat Trout populations and that have the greatest risk of postfire debris flows; and 3) use data on the spatial distribution and abundance of Colorado River Cutthroat Trout and their habitats to determine where postfire debris flows pose the greatest threat to reach- and basin-wide Colorado River Cutthroat Trout populations and habitat.

\section{STUDY AREA}

The study area in north-central Colorado encompasses the Colorado River upstream of Glenwood Springs, Colorado, and includes major tributaries of the Eagle and Blue Rivers (Fig. 1). Headwater streams in the upper Colorado River basin experience warm, dry summers. Annual precipitation ranges from 48 to $100 \mathrm{~cm}$, and most precipitation occurs during the winter as snow. Tributary watersheds are drained predominantly by small $1^{\text {st }}$ - and $2^{\text {nd }}$-order montane streams primarily situated on public lands administered by the USDA Forest Service and the US Department of the Interior National Park Service. Stream channels generally alternate between unconstrained meadow segments with channel gradients of 1 to $2 \%$ and constrained segments 


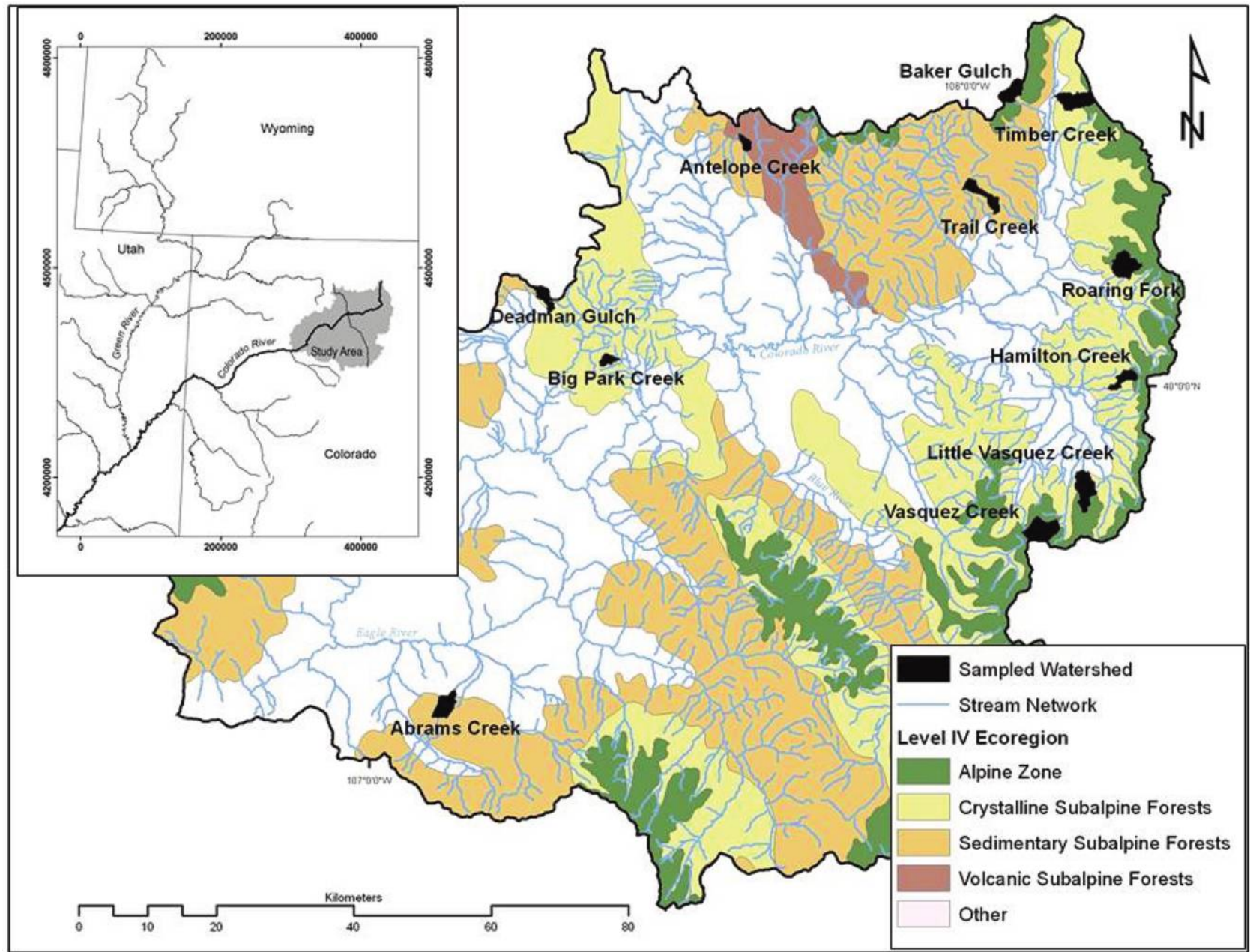

Figure 1. Study area in the upper Colorado River basin, Colorado, USA, and the distribution of 11 sampled watersheds among Environmental Protection Agency level IV ecoregion strata. All sampled watersheds were occupied by Colorado River Cutthroat Trout (Oncorhynchus clarkii pleuriticus).

where gradients can be $>5 \%$. Mean watershed elevations range from 2300 to $4000 \mathrm{~m}$ asl, and perennial stream length varies from 3 to $9 \mathrm{~km}$.

Riparian vegetation in meadow segments is dominated by sedges (Carex spp.) and willow (Salix spp.). In the steeper forested segments, mixed stands of lodgepole pine (Pinus contorta), subalpine fir (Abies lasioicarpa), Engelmann spruce (Picea engelmannii), and aspen (Populus tremuloides) are common. Stands of lodgepole pine have been regenerated by fires occurring during the last $400 \mathrm{y}$, but many of the spruce-subalpine fir stands have not burned for $>400 \mathrm{y}$ (Sibold et al 2006). Many of the mature lodgepole stands have become infested recently with mountain pine beetle (Dendroctonus ponderosae). The resulting landscape is characterized by thousands of hectares of standing dead trees and a dense understory of lodgepole seedlings.

Fire history in the study area is characterized by infrequent, large stand-replacing fires (Sibold et al. 2006).
Stand-replacing fires are the primary agent of disturbance for lodgepole pine forests, but blowdown, low-severity surface fires, and mountain pine beetle outbreaks also occur (Sibold et al. 2007). Regional-scale climate variation is the dominant factor influencing the occurrence of fire (Schoennagel et al. 2005, Sibold and Veblen 2006), but subsequent effects of fire on landscapes are modified by local- and meso-scale biotic and abiotic factors (Sibold et al. 2006, Bigler et al. 2007). Recent studies suggest that fire suppression has not had a significant effect on current forest conditions or fire frequency or size (Sibold et al. 2006).

\section{METHODS}

\section{Sample design}

Our study was focused on headwater watersheds in the upper Colorado River basin containing populations of Colorado River Cutthroat Trout, so we defined the sample unit as the watershed (Gresswell et al. 2004). Our ini- 
tial sampling frame consisted of 53 headwater watersheds $\left(1^{\text {st }}\right.$ and $2^{\text {nd }}$ orders, areas $=3-20 \mathrm{~km}^{2}$ ) that were situated on federal lands and supported genetically unaltered populations of Colorado River Cutthroat Trout isolated by natural or anthropogenic migration barriers (e.g., cascades, waterfalls, culverts, and water diversions). We expected vegetation type (e.g., forest, meadow, and unvegetated rock outcrops), geology, and elevation to influence the spatial distribution of fish and postfire debris flows in this region, so we created 4 sampling strata based on Geographic Information System (GIS) coverages to delineate level-IV ecoregions in the Southern Rocky Mountains (Alpine, Crystalline Subalpine, Sedimentary Subalpine, and Volcanic Subalpine ecoregions; 1:250,000 level-IV ecoregion coverage; USEPA 2005). We randomly selected 12 watersheds from the original sampling universe in proportion to the number of watersheds in each stratum. However, 1 watershed was later excluded when it was discovered that Brook Trout (Salvelinus fontinalis) had displaced native Colorado River Cutthroat Trout in that watershed (Fig. 1).

\section{Spatial distribution and abundance of Colorado River Cutthroat Trout and physical habitat}

We conducted spatially continuous fish and habitat surveys in all stream reaches occupied by trout in each of the 11 study watersheds to compare the distributions of Colorado River Cutthroat Trout and physical habitat with estimates of debris-flow risk. Prior to field surveys, we divided the channel network of each watershed into stream segments bounded by tributary junctions and barriers to movement (Frissell et al. 1986, Moore et al. 2007) on the basis of information from topographic and geologic maps, aerial photographs, and field reconnaissance (Gresswell et al. 2006).

We conducted physical habitat surveys when water levels were near base flow (July-September 2008, 2009). We divided individual segments into geomorphic reach types (meadow-trench, pool-riffle, plain bed, step-pool, or cascade) based on substrate size, gradient, bed morphology, and pool spacing (Montgomery and Buffington 1997). We measured channel slope (\% gradient) with a clinometer and averaged measurements for each reach. We estimated a valley width index (VWI) for each reach by dividing the mean valley floor width by the mean active channel width (Moore et al. 2007).

We classified channel-unit types, including pools, fast water (rapids, cascades), and steps, according to Bisson et al. (1982). We measured the length, width, and maximum depth of every pool and height of each vertical step $>0.5 \mathrm{~m}$ (nearest $0.1 \mathrm{~m}$ ). We classified substrate size based on visual estimates $( \pm 10 \%)$ of the dominant substrate type (Moore et al. 2007), including bedrock, boulder (>256 mm), cobble $(64-256 \mathrm{~mm})$, gravel $(2-63 \mathrm{~mm})$, and fines (sand, silt, and organics; $<2 \mathrm{~mm}$ ).
We estimated the abundance of Colorado River Cutthroat Trout in pools of each study watershed (Gresswell et al. 2006) with single-pass electrofishing, moving upstream from the lowest portion of each watershed to headwater areas (Bateman et al. 2005). We focused sampling on pools because Colorado River Cutthroat Trout, like many salmonids, are concentrated in pools during summer months (Young 2008). To identify the upstream extent of trout distribution, we sampled the main stem and tributaries for 50 to $300 \mathrm{~m}$ ( 10-40 individual pool units) beyond the point at which trout were not detected. Captured trout $\geq 70 \mathrm{~mm}$ (total length) were anesthetized (MS-222; concentration $=125 \mathrm{mg} / \mathrm{L}$ ), measured, and returned near the point of capture. We did not collect individuals $<70 \mathrm{~mm}$ (i.e., presumed age $<1$ y) (Bateman et al. 2005).

\section{Reach-scale debris-flow risk-assessment model}

To estimate the relative probability of debris flows in individual reaches of study watersheds, we developed a qualitative model based on 4 primary factors associated with the initiation and transport of debris flows (hillslope gradient, flow accumulation pathways, channel gradient, and valley confinement; Benda and Dunne 1997, Wondzell and King 2003). First, we developed a set of empirical rules for identifying initiation sites and flow accumulation pathways because debris flows start on hill slopes and are transported downstream by steep and confined stream channels. We identified initiation sites on the basis of a 10-m resolution DEM, and we evaluated hill slopes vulnerable to debris-flow initiation for each 10 -m pixel of $1^{\text {st }}$-order watersheds in the DEM. We restricted identification of debris-flow initiation areas to $1^{\text {st }}$-order watersheds because the hillslope characteristics of higher-order watersheds generally are not conducive to debris-flow initiation (Benda and Cundy 1990, Benda et al. 2005). We defined initiation sites as a linear cluster of at least nine $10-\mathrm{m}$ pixels (= 90-m-long axis; C. Luce, USDA Forest Service, personal communication) having a minimum $30 \%$ slope or initiating cells with $>30 \%$ slope next to a flow accumulation pathway (small tributary, ravine, draw, or rill; Cannon et al. 2010, Gartner et al. 2008). When pixel clusters met these criteria, we conducted a flow accumulation analysis to assess flow direction and accumulation in each downslope pixel. The entire drainage area of a stream reach was classified as an initiating area for debris flows if $\geq 1$ initiating cell was present in the watershed.

Debris flows and material transport are likely to propagate or continue in steep and confined pathways (Benda and Cundy 1990). The onset of deposition occurs when the stream valley widens (unconfined), allowing the material to spread out, and when the stream channel gradient decreases (Hungr et al. 2005; J. Gartner, US Geological Survey Denver, personal communication). Therefore, we estimated downstream movement or transport of debris flows 
by summing the length of conterminous reaches that had a mean gradient $>7 \%$ (Hungr et al. 2005) and were classified as confined (VWI < 2.5; Moore et al. 2007). The debrisflow path was assumed to continue downstream until it contacted a stream reach that did not meet these criteria.

We summarized this information and incorporated it into the reach-scale debris-flow model with each characteristic assigned a " + " if it supported initiation or propagation of a debris flow or a "-" if it supported sediment deposition or did not meet initiation or propagation criteria. Positive notations were summed to estimate the probability rank of a debris flow on a scale of 1 to 4 (low to high). To assess watershed-scale debris-flow probability, we multiplied the ranking score for each reach by the reach length, summed the resulting values for all reaches in a watershed, and divided the total by the length of stream surveyed in the watershed.

We displayed the results by mapping debris-flow risk for the 11 watersheds in ArcGIS (3D Spatial Analyst, version 9.3, Environmental Research Systems Institute, Redlands, California). We divided stream networks into reaches and displayed them according to debris-flow risk rankings by color coding from blue (low-probability risk, rank =1) to red (high-probability risk, rank $=4$ ). We integrated trout abundance with the map of debris-flow risk ranking to assess the vulnerability of local trout populations to debris flow.

\section{Statistical analyses}

We conducted all statistical analyses in the Number Cruncher Statistical System (Hintze 2007). We compared physical characteristics and Colorado River Cutthroat Trout abundance among watersheds, ecoregions, and reach types with analyses of variance (ANOVAs) followed by TukeyKramer multiple-comparisons tests when results were significant. We examined data for normality using skewness normality of residuals, kurtosis normality of residuals, omnibus normality of residuals, and modified Levene equalvariance tests. Where data were not normally distributed, we applied a $\sqrt{ }(x)$ transformation prior to analysis. We evaluated relationships among individual variables with Pearson product moment or Spearman rank correlation analyses, depending on whether data were distributed normally.

\section{RESULTS}

\section{Watershed characteristics}

Variation in the physical characteristics of the watersheds sampled in our study was substantial. For example, watershed areas ranged from 2.95 (Antelope Creek) to $14.48 \mathrm{~km}^{2}$ (Little Vasquez Creek), and mean elevation ranged from 2799 to $3534 \mathrm{~m}$ asl (Table 1). Surveyed stream length tended to increase with watershed area, but the relationship was not statistically significant (Pearson correlation, $r=0.50, p=0.12$; Table 1$)$. Mean reach length was significantly greater at Trail Creek $(1400 \mathrm{~m})$ than at Baker Gulch, Antelope Creek, Hamilton Creek, Abrams Creek, Vasquez Creek, and Roaring Fork (ANOVA, Tukey-Kramer, $p<0.05$; Table 1). Mean reach gradient varied among watersheds (ANOVA, $p=0.01$ ) and was highest at Baker Gulch (13.7\%) and lowest at Deadman Gulch and Big Park Creek (gradient $=2.6$ and $3.1 \%$, respectively). Pool length, maximum depth, and area also varied significantly among watersheds (ANOVAs, $p<0.05$; Table 1 ). Mean reach length in each watershed was positively correlated with the number of pools/reach and the mean length of pools/reach (Spearman Rank correlation, $r=0.53, r=0.52$, respectively; both $p<0.01$ ).

The greatest number of Colorado River Cutthroat Trout (mean $=70$ trout $/$ reach) was collected in Deadman Gulch, and numbers in other watersheds ranged from 6 (Vasquez Creek) to 22 trout/reach (Hamilton Creek). The mean number of Colorado River Cutthroat Trout/pool and trout density were lowest in Vasquez Creek (mean $=0.24$ trout $/$ pool and 0.02 trout $/ \mathrm{m}^{2}$, respectively) and highest in Deadman Gulch (1.95 trout/pool and 0.29 trout $\left./ \mathrm{m}^{2}\right)$. In general, the abundance of Colorado River Cutthroat Trout was directly linked to the amount of available pool habitat in occupied reaches of stream. The number of Colorado River Cutthroat Trout/reach was positively correlated (Spearman Rank Correlation, $p<0.01$ ) with the mean number of pools/reach $(r=0.64)$, mean total pool length $(r=$ $0.76)$, and mean pool area $(r=0.67)$, with weaker positive but significant $(p<0.01)$ correlations between the mean number of trout/pool and mean total pool length $(r=$ $0.33)$ and pool area $(r=0.43)$. Colorado River Cutthroat Trout densities were weakly but significantly positively related to mean stream width $(r=0.31)$ and mean maximum pool depth $(r=0.35)$ (Spearman Rank Correlation, $p<0.05)$.

Physical and biological characteristics of watersheds also varied by ecoregion. Mean reach length, mean number of pools/reach, and mean length of pools/reach were greatest in the Sedimentary Subalpine ecoregion (ANOVAs, $p=0.02, p<0.01$, and $p=0.04$, respectively). Mean gradient and mean pool width were highest in the Alpine ecoregion, and the mean number of Colorado River Cutthroat Trout per pool was lowest in the Alpine and Volcanic Subalpine ecoregions ( 0.57 and 0.26 trout/pool, respectively). The number of Colorado River Cutthroat Trout/reach was greatest in the Sedimentary Subalpine ecoregion (35 trout/ reach), and the Sedimentary Subalpine and Crystalline Subalpine ecoregions had the greatest number of Colorado River Cutthroat Trout/pool (0.91 and 0.75 trout/pool, respectively). Boulder and cobble substrates were most common in Alpine ecoregion streams, and the proportions of fines and gravel were greater in the Crystalline Subalpine, Sedimentary Subalpine, and Volcanic Subalpine ecoregions. Pool area, the number of steps, the number of steps $>1 \mathrm{~m}$, and the mean number of Colorado River Cutthroat Trout/ 
Table 1. Physical characteristics of the 11 watersheds sampled in the headwaters of the upper Colorado River basin, 2008-2009. Watershed-scale debris-flow probability rank was derived by multiplying the ranking score (1-4, where 1 is a low-probability-risk rank and 4 is a high-probability-risk rank) for a reach by the reach length, summing all reaches in the watershed, and dividing by the total length of stream surveyed. Ecoregions are: A = Alpine, CS = Crystalline Subalpine, SS = Sedimentary Subalpine, VS = Volcanic Subalpine; No. $=$ number.

\begin{tabular}{|c|c|c|c|c|c|c|c|c|c|c|c|}
\hline Watershed & $\begin{array}{l}\text { Level IV } \\
\text { ecoregion }\end{array}$ & $\begin{array}{c}\text { Watershed } \\
\text { area } \\
\left(\mathrm{km}^{2}\right)\end{array}$ & $\begin{array}{c}\text { Stream } \\
\text { length } \\
(\mathrm{km})\end{array}$ & $\begin{array}{c}\text { Mean } \\
\text { elevation } \\
(\mathrm{m})\end{array}$ & $\begin{array}{c}\text { Drainage } \\
\text { density } \\
\left(\mathrm{km} / \mathrm{km}^{2}\right)\end{array}$ & $\begin{array}{l}\text { No. of } \\
\text { reaches }\end{array}$ & $\begin{array}{c}\text { Mean } \\
\text { reach } \\
\text { length } \\
(\mathrm{m})\end{array}$ & $\begin{array}{c}\text { Mean } \\
\text { reach } \\
\text { gradient } \\
\quad(\%)\end{array}$ & $\begin{array}{c}\text { Mean } \\
\text { maximum } \\
\text { pool depth } \\
(\mathrm{m})\end{array}$ & $\begin{array}{c}\text { Debris-flow } \\
\text { probability } \\
\text { rank }\end{array}$ & $\begin{array}{l}\% \text { stream } \\
\text { with } \\
\text { reach-scale } \\
\text { rank }=3-4\end{array}$ \\
\hline Baker Gulch & A & 7.10 & 5.62 & 3505 & 0.79 & 9 & 432 & 13.7 & 0.39 & 2.8 & 70 \\
\hline Roaring Fork & A & 11.86 & 4.28 & 3350 & 1.02 & 6 & 642 & 11.0 & 0.60 & 2.5 & 52 \\
\hline Vasquez Creek & A & 13.21 & 7.81 & 3534 & 1.30 & 8 & 625 & 7.7 & 0.46 & 3.0 & 78 \\
\hline Big Park Creek & CS & 3.29 & 3.44 & 2799 & 2.91 & 3 & 767 & 3.1 & 0.28 & 2.1 & 40 \\
\hline Hamilton Creek & CS & 5.59 & 6.81 & 3253 & 1.23 & 7 & 491 & 7.5 & 0.44 & 1.8 & 28 \\
\hline Little Vasquez & CS & 14.48 & 6.12 & 3202 & 0.89 & 3 & 1133 & 8.1 & 0.50 & 2.4 & 28 \\
\hline Timber Creek & CS & 11.14 & 5.81 & 3316 & 0.88 & 6 & 916 & 9.6 & 0.64 & 2.8 & 75 \\
\hline Abrams Creek & SS & 8.94 & 8.11 & 2834 & 1.78 & 4 & 500 & 8.0 & 0.22 & 2.9 & 63 \\
\hline $\begin{array}{c}\text { Deadman } \\
\text { Gulch }\end{array}$ & SS & 5.13 & 5.18 & 2824 & 2.98 & 4 & 1090 & 2.6 & 0.38 & 1.4 & 0 \\
\hline Trail Creek & SS & 8.52 & 7.45 & 3125 & 0.96 & 5 & 1400 & 6.9 & 0.45 & 1.9 & 25 \\
\hline Antelope Creek & VS & 2.95 & 3.27 & 3068 & 4.94 & 3 & 467 & 5.9 & 0.25 & 1.8 & 0 \\
\hline
\end{tabular}

pool or trout density did not differ significantly among ecoregions (ANOVA, $p>0.05$ ).

\section{Reach-scale debris-flow risk-assessment model}

Six watersheds (Abrams Creek, Baker Gulch, Hamilton Creek, Little Vasquez Creek, Timber Creek, and Vasquez Creek) included $\geq 1$ reach, usually in the lower portion of the watersheds, with the highest debris-flow probability ranking (rank =4). The highest rank estimated for reaches in the Big Park Creek, Roaring Fork, and Trail Creek watersheds was 3 . The debris-flow probability rank for Antelope Creek and Deadman Gulch did not exceed 2. Headwaters of these high-elevation streams often were situated in lowgradient meadows. Channels subsequently descended rapidly downstream before reaching moderate gradients near major tributary junctions (all watersheds were isolated from mainstem rivers by barriers to the upstream movement of trout).

Watershed-scale debris-flow probability ranks (based on the weighted means of reach-scale ranks) ranged from 1.4 (Deadman Gulch) to 3.0 (Vasquez Creek) (Table 1). In watersheds with a rank $>2.5$, including all Alpine zone watersheds (Baker Gulch, Roaring Fork, and Vasquez Creek), Timber Creek, and Abrams Creek, $>50 \%$ of stream reaches had moderate-to-high debris-flow probability ranks (3 or 4). Timber and Vasquez Creeks had the greatest proportions of their reaches with the highest risk of debris flow (75 and $78 \%$, respectively of reaches).

\section{Spatial distribution and abundance of Colorado River Cutthroat Trout, physical habitat, and debris-flow risk}

Baker Gulch, Timber Creek, and Vasquez Creek had the greatest proportion of stream $(\geq 70 \%)$ with high risk of debris flow (Table 1), but the proportion of trout in the high-probability reaches was $<70 \%$ (Table 2). Indeed, $<50 \%$ of trout sampled in Baker Gulch and Abrams Creek were in areas of a high probability of debris flows (Table 2). In contrast, $40 \%$ of the Big Park Creek reaches had a high probability of debris flows (Table 1), but $83 \%$ of the trout captured in this stream network were found in high-risk areas (Table 2). Antelope Creek and Deadman Gulch had $0 \%$ of trout populations at a high-risk probability of debris flow, but in Hamilton Creek, Little Vazquez Creek, Roaring Fork, and Trail Creek, postfire debris flows could potentially affect 23 to $48 \%$ of the Colorado River Cutthroat Trout populations (Table 2).

The proportion of stream reaches with a reach-scale risk rank of 3 to 4 was highest in the Alpine ecoregion (mean $=67 \%$ ), followed by the Crystalline Subalpine (43\%) and the Sedimentary Subalpine ecoregions (29\%). None of the reaches in Antelope Creek (the only watershed in the Volcanic Subalpine ecoregion) had a rank $>2$ (Table 2). Despite these trends, no statistically significant differences were found among ecoregions in mean reach-scale risk rank (ANOVA, $p=0.17$ ) or weighted mean watershedscale risk rank $(p=0.36)$.

In contrast, the risk of debris flows varied significantly among reach types (ANOVA, $p<0.01$ ). Reach types that 
Table 2. The percentage of Colorado River Cutthroat Trout (Oncorhynchus clarkii pleuriticus) captured per watershed in each reach-scale debris-flow-risk ranking category (on a scale of 1-4, low- to high-probability risk) for watersheds in the upper Colorado River basin. High risk includes ranking categories 3 and 4.

\begin{tabular}{|c|c|c|c|c|c|c|c|c|}
\hline \multirow[b]{2}{*}{ Watershed } & \multicolumn{4}{|c|}{ Risk rank } & \multirow{2}{*}{$\begin{array}{c}\% \text { of trout at } \\
\text { high risk }\end{array}$} & \multirow{2}{*}{$\begin{array}{c}\text { Mean } \\
\text { trout/reach }\end{array}$} & \multirow{2}{*}{$\begin{array}{c}\text { Mean } \\
\text { trout/pool }\end{array}$} & \multirow{2}{*}{$\begin{array}{c}\text { Mean } \\
\text { trout } / \mathrm{m}\end{array}$} \\
\hline & 1 & 2 & 3 & 4 & & & & \\
\hline Abrams Creek & 0 & 52 & 30 & 18 & 48 & 19.8 & 0.39 & 0.11 \\
\hline Antelope Creek & 0 & 100 & 0 & 0 & 0 & 11.0 & 0.26 & 0.14 \\
\hline Baker Gulch & 24 & 33 & 38 & 5 & 43 & 18.7 & 0.85 & 0.09 \\
\hline Big Park Creek & 1 & 16 & 83 & 0 & 83 & 21.3 & 0.41 & 0.11 \\
\hline Deadman Gulch & 37 & 63 & 0 & 0 & 0 & 69.8 & 1.95 & 0.29 \\
\hline Hamilton Creek & 76 & 1 & 0 & 23 & 23 & 22.1 & 0.65 & 0.04 \\
\hline Little Vasquez Creek & 52 & 0 & 8 & 40 & 48 & 13.3 & 0.37 & 0.02 \\
\hline Roaring Fork & 0 & 74 & 26 & 0 & 26 & 9.0 & 0.58 & 0.05 \\
\hline Timber Creek & 32 & 0 & 15 & 53 & 68 & 21.7 & 1.24 & 0.07 \\
\hline Trail Creek & 36 & 35 & 29 & 0 & 29 & 20.2 & 0.49 & 0.04 \\
\hline Vasquez Creek & 22 & 9 & 24 & 44 & 68 & 5.6 & 0.24 & 0.02 \\
\hline
\end{tabular}

had a steep gradient (e.g., cascade, plain-bed, and steppool reaches) had a higher risk of debris flows than lowgradient reach types, such as meadow trenches and poolriffle reaches (Table 3). Low-gradient reaches tended to have more pool habitat (e.g., greater pool length and higher pool area) and a greater abundance of Colorado River Cutthroat Trout/pool (ANOVA, $p=0.01$ ) than did high-gradient reaches. For example, the density of Colorado River Cutthroat Trout was $>2 \times$ higher in pool-riffle reaches (mean $=$ 1.1 trout/pool) than in cascades ( 0.4 trout/pool).

The number of Colorado River Cutthroat Trout/pool varied significantly among reaches with different risk ranks (ANOVA, $p=0.03$ ). Paired comparisons (Tukey-Kramer multiple-comparisons test) yielded statistically significant differences in the number of trout/pool in reaches with a debris risk rank of 0 (mean $=1.2$ trout $/$ pool $)$ vs in those reaches with a risk rank $=3$ (mean $=0.6$ trout $/$ pool). Despite these differences, the correlation between the mean number of trout/pool in a reach and reach risk rank was not statistically significant (Spearman rank correlation, $r=$ $-0.23, p>0.05)$. The $2^{\text {nd }}$-highest number of trout/pool was collected in pools with a risk rank of 4 . At the watershed scale, the mean number of trout/pool and the weighted mean reach risk rank were not correlated (Spearman rank correlation, $r=-0.24, p>0.05)$.

\section{DISCUSSION}

We developed a reach-scale debris-flow risk-assessment model to examine the probability and extent of postfire debris flows within and among watersheds. To assess the potential ecological consequences of postfire debris flows in headwater streams of the upper Colorado River basin, we integrated our results with information on the distribution of Colorado River Cutthroat Trout and physical habitat at the reach scale. The reach-scale debris-flow riskassessment model provides direct linkages between hillslopes and stream channel networks by identifying debrisflow source areas and the propagation of debris flows down flow paths. The model can be used to display reaches that have the highest probability of being affected by postfire debris flows, thereby predicting the proportion of available

Table 3. Characteristics of geomorphic reach types found throughout the 11 watersheds in the headwaters of the upper Colorado River basin. All trout captured were Colorado River Cutthroat Trout (Oncorhynchus clarkii pleuriticus). Debris-flow probability rank is on a scale of 1 (low risk) to 4 (high risk). MT = meadow trench, $\mathrm{PR}=$ pool-riffle, $\mathrm{PB}=$ plain bed, $\mathrm{CA}=$ cascade, and $\mathrm{SP}=$ step-pool.

\begin{tabular}{lccccc}
\hline $\begin{array}{c}\text { Geomorphic } \\
\text { reach type }\end{array}$ & $\begin{array}{c}\text { Number of } \\
\text { reaches }\end{array}$ & $\begin{array}{c}\text { Mean reach } \\
\text { length }(\mathrm{m})\end{array}$ & $\begin{array}{c}\text { Mean } \\
\text { gradient }(\%)\end{array}$ & $\begin{array}{c}\text { Mean } \\
\text { trout/pool }\end{array}$ & $\begin{array}{c}\text { Mean debris-flow } \\
\text { probability rank }\end{array}$ \\
\hline MT & 5 & 878 & 3.6 & 0.58 & 1.0 \\
PR & 18 & 756 & 4.4 & 1.06 & 1.6 \\
PB & 16 & 807 & 11.0 & 0.61 & 2.8 \\
CA & 11 & 525 & 12.8 & 0.36 & 2.9 \\
SP & 8 & 680 & 9.8 & 0.52 & 2.9 \\
\hline
\end{tabular}


aquatic habitat potentially affected by debris flows. Understanding watershed and stream reach susceptibility to debris flows will improve our ability to predict habitat types, disturbance regimes, and the associated distribution and abundance of aquatic species over entire channel networks.

Results from the reach-scale debris-flow risk-assessment model suggest a moderate risk (mean debris-flow risk rank = 2.3) of postfire debris flows in watersheds of the upper Colorado River basin. Watersheds in the Alpine ecoregion have a higher probability of postfire debris flows than those at lower elevations. However, Alpine watersheds in our study tended to have more tributaries than watersheds at lower elevations. Therefore, a greater proportion of Alpine stream networks than networks at lower elevations could provide refugia from local disturbances (sensu Guy et al. 2008, Neville et al. 2009). Debris-flow potential was highest in the lower and middle reaches in most watersheds, even those in the Alpine ecoregion. However, Colorado River Cutthroat Trout were found throughout these watersheds, and a substantial proportion of trout pop- ulations occurred in high-elevation meadow reaches or lakes above points of debris-flow initiation and transport (Figs 2A-D, 3A-C, 4A-D).

Timber Creek had the greatest extent of stream channel with a risk rank of $4(>5 \mathrm{~km})$, and only $\sim 2 \mathrm{~km}$ of this stream had low debris-flow risk ranks. If the entire vulnerable portion of Timber Creek were affected by a debris flow, the remaining unaltered reaches would compose a linear stream distance less than that often cited for persistence of trout populations $(8 \mathrm{~km}$; Hilderbrand and Kershner 2000). Isolated populations in small drainages may be vulnerable to loss of genetic variability and stochastic extirpation (Kruse et al. 2001, Fausch et al. 2009), but evidence suggests that many may persist for decades or longer (Wofford et al. 2005, Guy et al. 2008, Cook et al. 2010). Furthermore, previous studies suggest that trout populations that are extirpated after postfire debris flows often return quickly to prefire densities if connectivity is maintained among reaches and tributaries (Gresswell 1999, Sestrich et al. 2011).

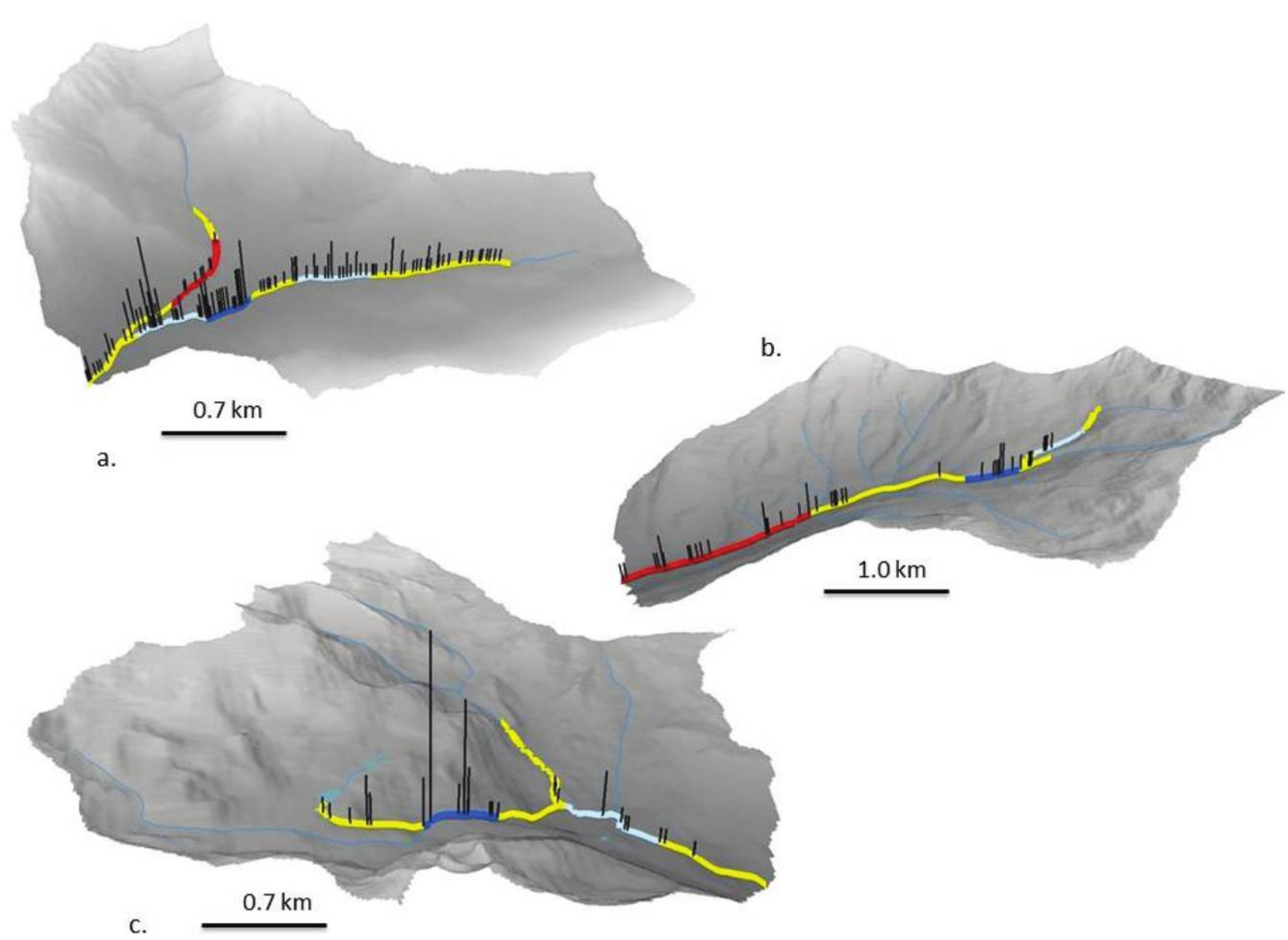

Figure 2. Spatial variation in the abundance (trout/pool) of Colorado River Cutthroat Trout (Oncorhynchus clarkii pleuriticus; length $>70 \mathrm{~mm}$ ) and debris-flow risk rank for Baker Gulch (a), Vasquez Creek (b), and Roaring Fork (c) stream reaches in the Alpine ecoregion. Vertical bars indicate the relative abundance (based on single-pass electrofishing) of Colorado River Cutthroat Trout sampled in pools. Debris-flow risk-assessment rank by stream reach is color-coded from low risk (dark blue) to high risk (red). 


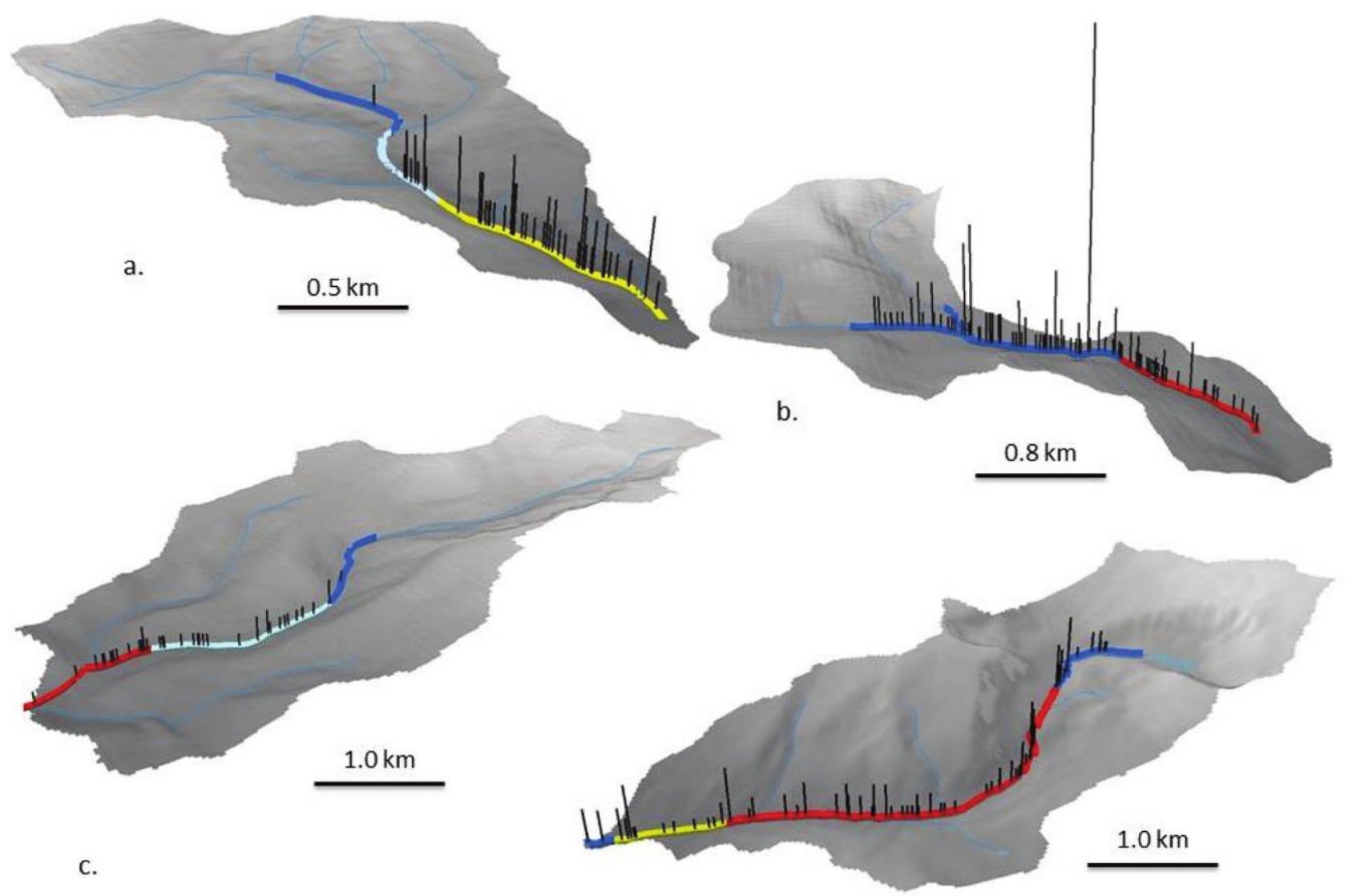

d.

Figure 3. Spatial variation in the abundance (trout/pool) of Colorado River Cutthroat Trout (Oncorhynchus clarkii pleuriticus; length $>70 \mathrm{~mm}$ ) and risk of debris flow for stream reaches Big Park Creek (a), Hamilton Creek (b), Little Vasquez Creek (c), and Timber Creek (c) in the Crystalline Subalpine ecoregion. Vertical bars indicate the relative abundance (based on single-pass electrofishing) of Colorado River Cutthroat Trout sampled in pools. Debris-flow risk-assessment rank by stream reach is color-coded from low risk (dark blue) to high risk (red).

Our results suggest that complete extirpation of trout populations by postfire debris flows is not likely in any of the level IV ecoregion types sampled in our study. In fact, Colorado River Cutthroat Trout were distributed throughout the accessible portions of all watersheds, including headwater lakes and meadows, well above the topographical influences of potential debris flows. Previous research suggests that trout in headwater lakes can colonize downstream stream reaches rapidly (Adams et al. 2001, Roghair et al. 2002). The effects of isolation are more pronounced in small linear stream sections because a loss of connectivity with other reaches or tributaries leaves small stream fragments that may be too small to support trout over extended periods (Fagan 2002, Guy et al. 2008, Neville et al. 2009).

One limitation of the reach-scale debris-flow riskassessment model is its inability to provide quantitative debris-flow estimates. This qualitative model can be used to identify reaches that are susceptible to debris flows but cannot be used to estimate the magnitude of associated effects. Debris flows often are initiated in a contributing tributary or hollow but subsequently stop upon entering the main channel (Whipple 1992, Lancaster et al. 2001, May and Gresswell 2004). Because the angle of the tributary is often nearly perpendicular to the main channel, only a short section of the main channel may be affected (May and Gresswell 2004). In other cases, debris flows may propagate into the main channel because the tributary junction is at an acute angle (Benda and Cundy 1990). This model was not designed to assess the magnitude or volume of sediment and wood entrained in debris flows but can be used to identify reaches of stream that are highly susceptible to effects of debris flow.

The advantage of the reach-scale debris-flow riskassessment model is that it is easy to use and requires only readily available field- and GIS-derived variables. The 4 physical characteristics of watersheds (hillslope gradient, flow accumulation pathways, channel gradient, and valley confinement) used in our model are directly related to the occurrence of debris flows (Benda and Dunne 1997, Won- 

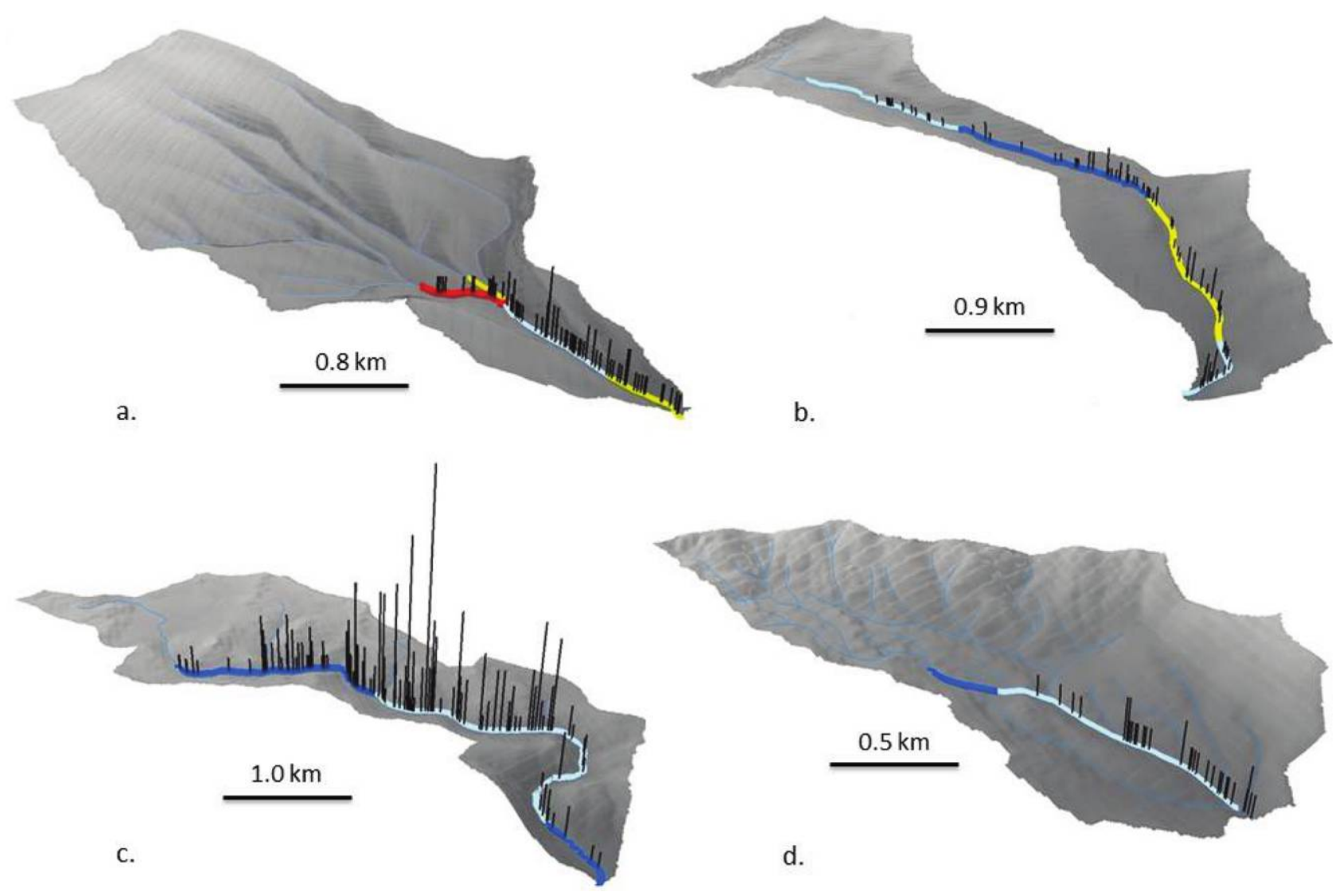

b.

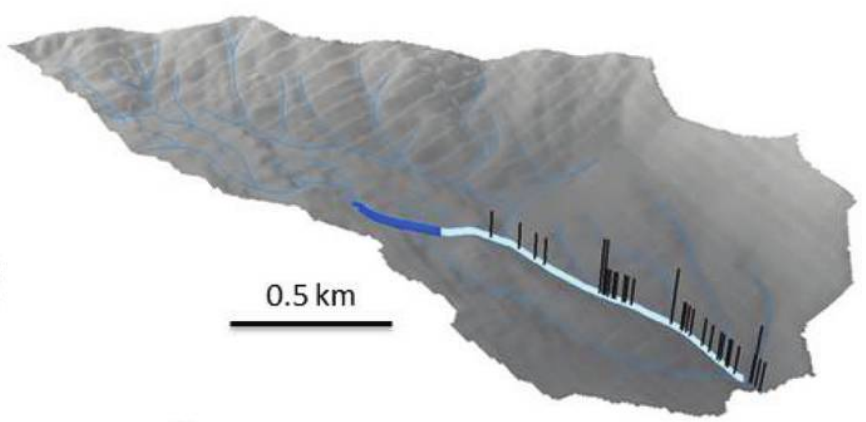

d.

Figure 4. Spatial variation in the abundance (trout/pool) of Colorado River Cutthroat Trout (Oncorhynchus clarkii pleuriticus; length $\geq 70 \mathrm{~mm}$ ) and risk of debris flow for stream reaches Abrams Creek (a), Trail Creek (b), and Deadman Gulch (c) in the Sedimentary Subalpine ecoregion and Antelope Creek (d) in the Volcanic Subalpine ecoregion. Vertical bars indicate the relative abundance (based on single-pass electrofishing) of Colorado River Cutthroat Trout sampled in pools. Debris-flow risk-assessment rank by stream reach is color-coded from low risk (dark blue) to high risk (red).

dzell and King 2003, Cannon et al. 2010). These 4 characteristics are not completely independent, but this fact does not affect the outcome. This qualitative model was intended to give a relative index of risk of debris flow, and we assume that the existence of an increasing number of individual factors increases the risk. The criteria used for each watershed characteristic in the model are not absolute: required thresholds for debris-flow initiation, propagation, and transport and debris flows can occur at lower values for each factor. However, the purpose of the model is to identify reaches of high risk, which can be identified by the summation of factors that exceed their respective thresholds. In the end, debris flows cannot occur anywhere without an initiating precipitation event and, given an extreme precipitation event, the presence of even one of these factors alone could possibly result in a mass failure and resulting debris flow. We chose to use an additive approach, but the relationship among these risk factors is undoubtedly more complex. Therefore, the risk of debris flow predicted by this model may be underestimated. However, the model does provide a reasonably in- expensive (Sedell 2013), easily applied first approximation of debris-flow risk that can be applied at the landscape scale.

Validation of this type of model is difficult because the process being modeled is strongly influenced by 2 stochastic factors, fire and precipitation. Previous researchers have documented that the risks of debris flow and flooding increase following wildfire but that these events are influenced by the intensity, extent, and severity of the fire, the geology and geomorphology of the watershed, and the timing, intensity, frequency, and duration of postfire precipitation events (Gresswell 1999). Even in unburned watersheds, debris flows can occur after heavy rainstorms (Wondzell and King 2003). The exact location and severity of wildfires and the intensity and duration of postfire precipitation events are virtually impossible to predict, but our model can provide useful insights for conceptualizing and planning for potential fire effects (Rieman et al. 2003, 2010, 2012).

The reach-scale debris-flow risk-assessment model has substantial heuristic value. For example, by examining the 
watershed with high-resolution information on topographic and stream channel characteristics and trout abundance, the potential effects of a postfire debris flow on isolated populations of native salmonids can be assessed. Our and similar models provide a proactive approach to the conservation and protection of native fishes given increased wildfire frequency and intensity associated with climate change. Examining the physical characteristics and processes of watersheds that contribute to postfire debris flows can provide input to decision-support models used to assess landscape resilience and long-term persistence of isolated populations in conjunction with available habitat, temperature, and connectivity (Williams et al. 2009, Luce et al. 2012).

Emerging conceptual frameworks in riverine ecology emphasize the importance of habitat heterogeneity, stochastic disturbances, and scaling issues (Schlosser 1991, Fausch et al. 2002, Poole 2002). However, these frameworks are often hindered by insufficient understanding of the physical basis for predicting the interactive effects of stochastic disturbances and channel network topology on fish habitats, distributions, and population dynamics (Benda et al. 2004, Ganio et al. 2005, Torgersen et al. 2006). We collected spatially continuous data throughout each watershed to examine relationships between debris-flow risk and trout populations at both watershed and reach scales. Our results underscore the importance of the heterogeneity of the physical habitat template in driving trout distributions and abundances. Our approach facilitates exploration of the physical foundations of spatially explicit phenomena (e.g., debris flows) and subsequent effects on the distribution and abundance of salmonids.

\section{ACKNOWLEDGEMENTS}

Funding for this project was furnished by the US Geological Survey and the Department of Ecology, Montana State University. We thank W. F. Cross, S. H. Cannon, J. E. Gartner, and J. P. Michael for discussions that helped to shape this project. C. L. May offered insights concerning the approach to reach-scale debris-flow modeling. B. Griffis, Z. Betz, and D. Reynolds assisted with field sampling and K. Larkin provided information concerning the distribution of Colorado River Cutthroat Trout in the study area. C. E. Torgersen, W. F. Cross, A. S. Todd, and 3 anonymous referees offered numerous suggestions that greatly improved this paper. Any use of trade, firm, or product names is for descriptive purposes only and does not imply endorsement by the US Government.

\section{LITERATURE CITED}

Adams, S. B., C. A. Frissell, and B. E. Rieman. 2001. Geography of invasion in mountain streams: consequences of headwater lake fish introductions. Ecosystems 4:296-307.

Bateman, D. S., R. E. Gresswell, and C. E. Torgersen. 2005. Evaluating single-pass catch as a tool for identifying spatial pattern in fish distribution. Journal of Freshwater Ecology 20: 335-345.

Behnke, R. J. 1992. Native trout of western North America. American Fisheries Society, Bethesda, Maryland.

Benda, L. E., and T. W. Cundy. 1990. Predicting deposition of debris flows in mountain channels. Canadian Geotechnical Journal 27:409-417.

Benda, L., and T. Dunne. 1997. Stochastic forcing of sediment supply to channel networks from landsliding and debris flow. Water Resources Research 33:2849-2863.

Benda, L., M. A. Hassan, M. Church, and C. L. May. 2005. Geomorphology of steepland headwaters: the transition from hillslopes to channels. Journal of the American Water Resources Association 41:835-851.

Benda, L., D. Miller, K. Andras, P. Bigelow, G. Reeves, and D. Michael. 2007. NetMap: a new tool in support of watershed science and resource management. Forest Science 53: 206-219.

Benda, L., N. L. Poff, D. Miller, T. Dunne, G. Reeves, G. Pess, and M. Pollock. 2004. The network dynamics hypothesis: how channel networks structure riverine habitats. BioScience 54:413-427.

Bigler, C., D. G. Gavin, C. Gunning, and T. T. Veblen. 2007. Drought induces lagged tree mortality in a subalpine forest in the Rocky Mountains. Oikos 116:1983-1994.

Bisson, P. A., J. L. Nielsen, R. A. Palmasono, and L. E. Grove. 1982. A system of naming habitat types in small streams, with examples of habitat utilization by salmonids during low streamflow. Pages 62-73 in N. B. Armantrout (editor). Acquisition and utilization of aquatic habitat inventory information. Western Division, American Fisheries Society, Bethesda, Maryland.

Brown, D. K., A. A. Echelle, D. L. Propst, J. E. Brooks, and W. L. Fisher. 2001. Catastrophic wildfire and numbers of populations as factors influencing risk of extinction for Gila Trout (Oncorhynchus gilae). Western North American Naturalist 61:139-148.

Cannon, S. H., J. E. Gartner, M. G. Rupert, J. A. Michael, A. H. Rea, and C. Parrett. 2010. Predicting the probability and volume of post-wildfire debris flows in the intermountain western United States. Geologic Society of America Bulletin 122:127-144.

Cannon, S. H., J. E. Gartner, M. G. Rupert, J. A. Michael, D. M. Staley, and B. B. Worstell. 2009. Emergency assessment of postfire debris-flow hazard for the 2009 Station fire, San Gabriel Mountains southern California. US Geological Survey Open-File Report 2009-1227. US Geological Survey, Reston, Virginia.

Cook, N., F. J. Rahel, and W. A. Hubert. 2010. Persistence of Colorado River Cutthroat Trout populations in isolated headwater streams of Wyoming. Transactions of the American Fisheries Societv 139:1500-1510.

CRCT (Colorado River Cutthroat Trout) Coordination Team. 2006. Conservation strategy for Colorado River Cutthroat Trout (Oncorhynchus clarkii pleuriticus) in the States of Colorado, Utah, and Wyoming. Colorado Division of Wildlife, Fort Collins, Colorado. (Available from: https://cpw.state.co.us /Documents/Research/Aquatic/pdf/CRCT_Conservation_Strategy _Jun06.pdf) 
Fagan, W. F. 2002. Connectivity, fragmentation, and extinction risk in dendritic metapopulations. Ecology 83:3243-3249.

Fausch, K. D., B. E. Rieman, J. B. Dunham, M. K. Young, and D. P. Peterson. 2009. Invasion versus isolation: trade-offs in managing native salmonids with barriers to upstream movement. Conservation Biology 23:859-870.

Fausch, K. D., C. E. Torgersen, C. V. Baxter, and H. W. Li. 2002. Landscapes to riverscapes: bridging the gap between research and conservation of stream fishes. BioScience 52:483-498.

Frissell, C. A., W. J. Liss, C. E. Warren, and M. D. Hurley. 1986. A hierarchical framework for stream classification: viewing streams in a watershed context. Environmental Management 10:199-214.

Ganio, L. M., C. E. Torgersen, and R. E. Gresswell. 2005. Describing spatial pattern in stream networks: a practical approach. Frontiers in Ecology and the Environment 3:138-144.

Gartner, J. E., S. H. Cannon, and P. M. Santi. 2011. Implementation of post-fire debris-flow hazard assessments along drainage networks, Southern California, U.S.A. Pages 855863 in Proceedings of the $5^{\text {th }}$ International Conference on Debris Flow Hazards Mitigation/Mechanics, Prediction, and Assessment Padua, Italy, June 7-11, 2011. Italian Journal of Engineering Geology and Environment-Book: Casa Editrice Universita La Sapienza, Rome. Italy.

Gartner, J. E., S. H. Cannon, P. M. Santi, and V. G. Dewolfe. 2008. Empirical models to predict the volumes of debris flows generated by recently burned basins in the western US. Geomorphology 96:339-354.

Gresswell, R. E. 1988. Status and management of interior stocks of Cutthroat Trout. Symposium 4. American Fisheries Society, Bethesda, Maryland.

Gresswell, R. E. 1999. Fire and aquatic ecosystems in forested biomes of North America. Transactions of the American Fisheries Society 128:193-221.

Gresswell, R. E., D. S. Bateman, G. W. Lienkaemper, and T. J. Guy. 2004. Geospatial techniques for developing a sampling frame of watersheds across a region. Pages 517-530 in T. Nishida, P. J. Kailola, and C. E. Hollingworth (editors). GIS/ spatial analyses in fishery and aquatic sciences. Volume 2. Fishery-Aquatic GIS Research Group, Saitama, Japan.

Gresswell, R. E., C. E. Torgersen, D. S. Bateman, T. J. Guy, S. R. Hendricks, and J. E. B. Wofford. 2006. A spatially explicit approach for evaluating relationships among Coastal Cutthroat Trout, habitat, and disturbance in headwater streams. Pages 457-471 in R. Hughes, L. Wang, and P. Seelbach (editors). Influences of landscapes on stream habitats and biological assemblages. American Fisheries Society, Bethesda, Maryland.

Guy, T. J., R. E. Gresswell, and M. A. Banks. 2008. Landscapescale evaluation of genetic structure among barrier-isolated populations of Coastal Cutthroat Trout, Oncorhynchus clarki clarki. Canadian Journal of Fisheries and Aquatic Sciences 65: 1749-1762.

Harig, A. L., and K. D. Fausch. 2002. Minimum habitat requirements for establishing translocated Cutthroat Trout populations. Ecological Applications 12:535-551.

Hilderbrand, R. H., and J. L. Kershner. 2000. Conserving inland Cutthroat Trout in small streams: how much stream is enough? North American Journal of Fisheries Management 20:513520.
Hintze, J. 2007. NCSS md GESS. NCSS, Kaysville, Utah.

Hirsch, C. L., M. R. Dare, and S. E. Albeke. 2013. Range-wide status of Colorado River Cutthroat Trout (Oncorhynchus clarkii pleuriticus): 2010. Colorado River Cutthroat Trout Conservation Team Report. Colorado Parks and Wildlife, Fort Collins, Colorado. (Available from: https://cpw.state.co.us/Documents /Research/Aquatic/CutthroatTrout/CRCTRangewideAssessment -08.04.2013.pdf)

Hungr, O., S. McDougall, and M. Bovis. 2005. Entrainment of material by debris flows. Pages 135-158 in M. Jakob and O. Hungr (editors). Debris flow hazards and related phenomena. Springer Verlag Praxis, Berlin, Germany.

Kruse, C. G., W. A. Hubert, and F. J. Rahel. 2001. An assessment of headwater isolation as a conservation strategy for Cutthroat Trout in the Absaroka Mountains of Wyoming. Northwest Science 75:1-11.

Lancaster, S. T., S. K. Hayes, and G. E. Grant. 2001. Modeling sediment and wood storage and dynamics in small mountainous watersheds. Pages 85-102 in J. M. Dorava, D. R. Montgomery, B. B. Palcsak, and F. A. Fitzpatrick (editors). Geomorphic processes and riverine habitat. American Geophysical Union, Washington, DC.

Luce, C., P. Morgan, K. Dwire, D. Isaak, Z. Holden, and B. Rieman. 2012. Climate change, forests, fire, water, and fish: building resilient landscapes, streams, and managers. General Technical Report RMRS-GTR-290. US Department of Agriculture, Forest Service, Rocky Mountain Research Station, Fort Collins, Colorado.

May, C. L., and R. E. Gresswell. 2004. Spatial and temporal patterns of debris-flow deposition in the Oregon Coast Range, USA. Geomorphology 57:135-149.

May, C. L., and T. E. Lisle. 2012. River profile controls on channel morphology, debris flow disturbance, and the spatial extent of salmonids in steep mountain streams. Iournal of Geophysical Research 117:1-15.

Montgomery, D. R., and J. M. Buffington. 1997. Channel-reach morphology in mountain drainage basins. Geological Society of America Bulletin 109:596-611.

Moore, K. M. S., K. K. Jones, and J. M. Dambacher. 2007. Methods for stream habitat surveys: Aquatic Inventories Project. Information Report 2007-01, version 3. Oregon Department of Fish and Wildlife, Corvallis, Oregon. (Available from: http://oregonstate.edu/dept/ODFW/freshwater/inventory /pdffiles/HabMethodsInfoReport2007-01.pdf)

Neville, H., J. Dunham, A. Rosenberger, J. Umek, and B. Nelson. 2009. Influences of wildfire, habitat size, and connectivity on trout in headwater streams revealed by patterns of genetic diversity. Transactions of the American Fisheries Society 138:1314-1327.

Parrett, C., S. H. Cannon, and K. L. Pierce. 2003. Wildfirerelated floods and debris flows in Montana in 2000 and 2001. US Geological Survey Water-Resources Investigation Report 03-4319. US Geological Survey, Reston, Virginia.

Peterson, D. P., B. E. Rieman, J. B. Dunham, K. D. Fausch, and M. K. Young. 2008. Analysis of trade-offs between threats of invasion by nonnative Brook Trout (Salvelinus fontinalis) and intentional isolation for native westslope Cutthroat Trout (Oncorhynchus clarkii lewisi). Canadian Journal of Fisheries and Aquatic Sciences 65:557-573. 
Poole, G. C. 2002. Fluvial landscape ecology: addressing uniqueness within the river discontinuum. Freshwater Biology 47:641660.

Propst, D. L., and J. A. Stefferud. 1997. Population dynamics of Gila Trout in the Gila River drainage of the southwestern United States. Journal of Fish Biology 51:1137-1154.

Reeves, G. H., L. E. Benda, K. M. Burnett, P. A. Bisson, and J. R. Sedell. 1995. A disturbance-based ecosystem approach to maintaining and restoring freshwater habitats of evolutionarily significant units of anadromous salmonids in the Pacific Northwest. Pages 334-349 in J. L. Nielsen (editor). Evolution and the aquatic ecosystem: defining unique units in population conservation. Symposium 17. American Fisheries Society, Bethesda, Maryland.

Rieman, B. E., and J. Clayton. 1997. Wildfire and native fish: issues of forest health and conservation of sensitive species. Fisheries 22(11):6-15.

Rieman, B. E., R. E. Gresswell, and J. Rinne. 2012. Fire and fish: a synthesis of observation and experience. Pages 159-175 in C. Luce, P. Morgan, K. Dwire, D. Isaak, Z. Holden, and B. Rieman (editors). Climate change, forests, fire, water, and fish: building resilient landscapes, streams, and managers. General Technical Report RMRS-GTR-290. US Department of Agriculture, Forest Service, Rocky Mountain Research Station, Fort Collins, Colorado.

Rieman, B. E., P. F. Hessburg, C. Luce, and M. R. Dare. 2010. Wildfire and management of forests and native fishes: conflict or opportunity for convergent solutions. BioScience 60:460-468.

Rieman, B., D. Lee, D. Burns, R. Gresswell, M. Young, R. Stowell, J. Rinne, and P. Howell. 2003. Status of native fishes in the western United States and issues for fire and fuels management. Forest Ecology and Management 178:197-211.

Rinne, J. N. 1996. Short-term effects of wildfire on fishes and aquatic macroinvertebrates in the southwestern United States. North American Journal of Fisheries Management 16:653-658.

Roghair, C. N., C. A. Dolloff, and M. K. Underwood. 2002. Response of a brook trout population and instream habitat to a catastrophic flood and debris flow. Transactions of the American Fisheries Society 131:718-730.

Rosenberger, A. E., J. B. Dunham, J. M. Buffington, and M. S. Wipfil. 2011. Persistent effects of wildfire and debris flows on the invertebrate prey base of Rainbow Trout in Idaho streams. Northwest Science 85:55-63.

Schlosser, I. J. 1991. Stream fish ecology: a landscape perspective. BioScience 41:704-712.

Schoennagel, T., T. T. Veblen, W. H. Romme, J. S. Sibold, and E. R. Cook. 2005. ENSO and PDO variability affect droughtinduced fire occurrence in Rocky Mountain subalpine forests. Ecological Applications 15:2000-2014.

Sedell, E. R. 2013. Predicting the spatial distribution of postfire debris flows and potential consequences to native trout in headwater stream networks. MS Thesis, Montana State University, Bozeman, Montana.

Sedell, J. R., G. H. Reeves, F. R. Hauer, J. A. Stanford, and C. P. Hawkins. 1990. Role of refugia in recovery from disturbances: modern fragmented and disconnected river systems. Environmental Management 14:711-724.
Sestrich, C. M., T. E. McMahon, and M. K. Young. 2011. Influence of fire on native and nonnative salmonid populations and habitat in a western Montana basin. Transactions of the American Fisheries Society 140:136-146.

Shepard, B. B., B. E. May, and W. Urie. 2005. Status and conservation of Westslope Cutthroat Trout within the western United States. North American Journal of Fisheries Management 25:1426-1440.

Sibold, J. S., and T. T. Veblen. 2006. Relationships of subalpine forest fires in the Colorado Front Range with interannual and multidecadal-scale climatic variation. Journal of Biogeography 33:833-842.

Sibold, J. S., T. T. Veblen, K. Chipko, L. Lawson, E. Mathis, and J. Scott. 2007. Influences of secondary disturbances on lodgepole pine stand development in Rocky Mountain National Park. Ecological Applications 17:1638-1655.

Sibold, J. S., T. T. Veblen, and M. E. Gonzalez. 2006. Spatial and temporal variation in historic fire regimes in subalpine forests across the Colorado Front Range in Rocky Mountain National Park, Colorado, USA. Journal of Biogeography 32:631-647.

Torgersen, C. E., C. V. Baxter, H. W. Li, and B. A. McIntosh. 2006. Landscape influences on longitudinal patterns of river fishes: spatially continuous analysis of fish-habitat relationships. Pages 473-492 in R. M. Hughes, L. Wang, and P. W. Seelbach (editors). Landscape influences on stream habitats and biological assemblages. Symposium 48. American Fisheries Society, Bethesda, Maryland.

USEPA (US Environmental Protection Agency). 2005. Level III and IV ecoregions of Colorado, version 1. US Environmental Protection Agency, Washington, DC. (Available from: http:// www.epa.gov/wed/pages/ecoregions/co_eco.htm)

Whipple, K. X. 1992. Predicting debris-flow runout and deposition on fans: the importance of the flow hydrograph. Pages 337-345 in D. Walling, T. Davies, and B. Hasholt (editors). Erosion, Debris-flows and Environment in Mountain Regions: Proceedings of the Chengdu Symposium. International Association of Hydrological Sciences, Chengdu, China.

Williams, J. E., A. L. Haak, H. M. Neville, and W. T. Colyer. 2009. Potential consequences of climate change to persistence of Cutthroat Trout populations. North American Journal of Fisheries Management 29:533-548.

Wofford, J. E. B., R. E. Gresswell, and M. A. Banks. 2005. Influence of barriers to movement on within-watershed genetic variation of Coastal Cutthroat Trout. Ecological Applications 15:628-637.

Wondzell, S. M., and J. G. King. 2003. Postfire erosional processes in the Pacific Northwest and Rocky Mountain regions. Forest Ecology and Management 178:75-87.

Young, M. K. 1995. Conservation assessment for inland Cutthroat Trout. General Technical Report RM-GTR-256. Rocky Mountain Forest and Range Experiment Station, US Department of Agriculture, Forest Service, Missoula, Montana.

Young, M. K. 2008. Colorado River Cutthroat Trout (Oncorhynchus clarkii pleuriticus): a technical conservation assessment. General Technical Report RMRS-GTR-207. Rocky Mountain Research Station, US Department of Agriculture, Forest Service, Missoula, Montana. 